IRA-International Journal of Management \& Social Sciences

ISSN 2455-2267; Vol.06, Issue 02 (2017)

Pg. no. 260-263

Institute of Research Advances

https://research-advances.org/index.php/RAJMSS

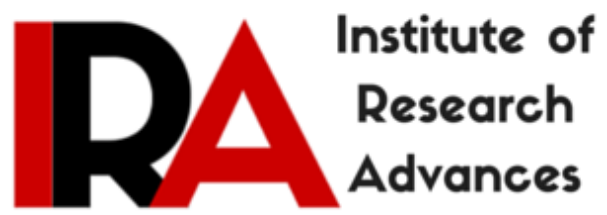

\title{
A Review of the Similarities and Differences in the Perspectives on Caste Adopted by Louis Dumont and B.R. Ambedkar
}

\section{Priya Bharti Churiyana}

Research Scholar

Delhi University, New Delhi, India.

Type of Review: Peer Reviewed.

DOI: http://dx.doi.org/10.21013/jmss.v6.n2.p9

\section{How to cite this paper:}

Churiyana, P. (2017). A Review of the Similarities and Differences in the Perspectives on Caste Adopted by Louis Dumont and B.R. Ambedkar. IRA-International Journal of Management \& Social Sciences (ISSN 2455-2267), 6(2), 260-263. doi:http://dx.doi.org/10.21013/jmss.v6.n2.p9

(C) Institute of Research Advances

\section{(cc) EY-NC}

This work is licensed under a Creative Commons Attribution-Non Commercial 4.0 International License subject to proper citation to the publication source of the work.

Disclaimer: The scholarly papers as reviewed and published by the Institute of Research Advances (IRA) are the views and opinions of their respective authors and are not the views or opinions of the IRA. The IRA disclaims of any harm or loss caused due to the published content to any party. 


\section{Dumont's Perspective on Caste System}

Dumont's perspective on caste system was primarily concerned with the ideology of the caste system. His understanding of caste lays emphasis on attributes of caste that is why his approach is called attributional approach to the caste system. For him caste is set of relationships of economic, political and kinship systems, sustained by certain values which are mostly religious in nature. Hierarchy in modern western sense has been replaced by the term social stratification which itself proves to be hindrance in the understanding of the peculiarities of caste system in India. Caste is not a form of social stratification, the ideology of caste system is directly contradicted to egalitarian theory of west ${ }^{1}$. Dumont argues that if caste is a social stratification than caste and social class are phenomena of same nature, (2) that hierarchy is incomprehensible, (3) that in the Indian system the separation and the interdependence of groups are subordinated to this sort of obscure or shamefaced hierarchy (hierarchy itself is shame faced) caste is a limiting case of social class in modern sense of the term.

Dumont agrees with Bougle's definition of caste system as system that divides the whole society into a large number of hereditary groups, distinguished from one another and connected together by three characteristics. Separation in matters of marriage and contact, whether direct or indirect food, division of labour, each group having in the theory or by tradition, a profession from which their member can depart only with certain limits finally hierarchy, which ranks the group as relatively superior to one another. Dumont says that caste is not a form of stratification but a special form of inequality whose essence has to be deciphered by the sociologists. Here he identifies hierarchy as the essential value underlying the caste system supported by Hinduism.

Dumont highlights the state of mind which is expressed by the emergence in various situations of castes. He calls caste system as a system of ideas and values which is a formal comprehensible rational system. His analysis is based on a single principle-the opposition of pure and impure. This opposition underlies hierarchy which means superiority of the pure and inferiority of impure. This principle also underlies separation which means pure and impure must be kept separate. According to Dumont the study of the caste system is useful for the knowledge of India and it is an important task of general sociology. He focused on the need to understand the ideology of caste as reflected in the classical texts, historical examples etc. He advocated the use of an Ideological and structuralist approach to the study of caste system and village social structure in India.

This opposition underlies hierarchy, which is the superiority of the pure to the impure, underlies separation because the pure and the impure must be kept separate and underlies the DOL because of pure and impure occupation must like wise be kept separate. The whole is founded on the necessary and hierarchical coexistence of the two opposites ${ }^{2}$.

While Ambedkar agrees with Dr. Ketkar definition of caste as a social group having two characteristics. 1. Membership is confined to those who are born of members and includes all persons so born. 2. The members are forbidden by an inexorable social law to marry outside the group. i.e Prohibition of intermarriage (endogamy) limits the membership to those born within the group and membership by autogeny as the 2 characteristics of caste. For Ambedkar this is the essence of caste, i.e endogamy is the characteristic peculiar to caste. The final analysis creation of castes, so far as India is concerned, means the superimposition of endogamy on exogamy means the creation of caste.

Caste and Profession: - For Dumont there is a definite relationship between caste and profession. This is not simply an identity. It is not purely and simply a professional system and is not same as professional guilds. For him the link between caste and profession is primarily a matter of status, that the important thing is the hereditary profession provided it is not contradicted by following too inferior a profession, and that the system has probably always carried with it some plasticity of this sort, while the village specialities, ritual or other, constitute its solid core .

\footnotetext{
${ }^{1}$ Homohirarchicus. p. 4

${ }^{2}$ Ibid. p.43
} 
For Ambedkar caste is not merely a division of labour. It is also a division of labourer. It is a hierarchy in which the divisions of labourer are graded one above the other. In no other country is the division of labour accompanied by this gradation of labourers. In caste system in India division of labour is not based on natural aptitude, social and individual efficiency, trained capacities but on that of the social status of parents i.e it is Ascribed status. Caste system does not allow Hindus to take occupation which they want to do if they do not belong to them by heredity. Caste system does not permit readjustment of occupation. For him caste becomes a direct cause of much of unemployment in the India. The division of labour is not a division based on choice, individual sentiment, individual preference, rather it is based on the dogma of pre-destination. Caste as an economic organization is therefore a harmful institution, as it involves the subordination of man's natural powers and inclinations to the exigencies of social rules.

Pure- Impure- Purity and pollution or we can say that pure and impure both plays an important role for both Ambedkar and Dumont. For Dumont pure and Impure determines to whom one can have a contact, Marriage, and giving and accepting food, Kuchha and Puckka. i.e the relations in the Hindu society are depended upon the purity and impurity level of a person. Dumont talks about temporary and permanent impurity For example in case of death, birth and other events in personal or family life are considered to harbour a danger which leads to the temporary seclusion of the affected persons, to prohibit against contact etc. ${ }^{3}$ The caste system comprises the specialization and interdependence of the constituent groups. Specialisation entails separation between these groups, but it is oriented towards the need of the whole. This relationship to the whole, repeatedly emphasized, links the Division of labour with hierarchy.

Religion- For Dumont Caste system is based on religion and has a positive function, one can not question religion as it is other worldly. While Ambedkar on the question of caste as Eugenic origin of caste argues that Manu did not give the law of caste and Manu could not do so. Caste existed long before Manu. For Ambedkar the Hindu society was somehow moulded into framework of the caste system and that it is an organization consciously created by the shastras. People does not only belief in Shastras but justifies that shastras cannot be wrong. Because of the religious sancitity caste system is still alive. He is focussing on the falsity of attitude that has exalted religious sanction to the position of a scientific explanation. For him it is the Hindu religion that have given so much so importance to the question of purity and Pollution i.e The Brahamin's primary Concern is to protect 'his interest' against those of the non Brahmins and the non -Brahmin's primary concern is to protect their interest against those of the Brahmins. For Dumont caste is as whole. while Ambedkar The Hindus, therefore are not merely an assortment of castes but they are so many warring groups each living for its selfish ideals. Caste is anti-social (interest of its own) which shut it out from full interaction with other group, so that its prevailing purpose is protection of what it has got. For Ambedkar the definition of caste from Senart and the 'idea of Pollution' as the characteristics of caste. For him it is only because the caste that enjoys the highest rank is the priestly caste: priest and purity are old associates, therefore the idea of pollution is the characteristic of caste only in so far as caste has a religious flavour. Quoting Nesfield that caste being a self-enclosed unit and there is an absence of messing with outsiders is not due to positive prohibition, but for Ambedkar it is a natural result of caste, i.e. Exclusiveness ${ }^{4}$. Dumont finds caste system as not only religious but over and above all i.e. not this worldly rather other worldly. While Ambedkar on the idea of pollution and purity, for him it has been attached to the institution of caste, only because the caste that enjoys the highest ranks is the priestly caste. Idea of pollution is a characteristic of caste only in so far as caste has a religious flavour.

Similarity- Both shared the view that caste is not an isolated unit by itself and not as a group with in, and with definite relations to. The caste is a system as a whole. Both have taken account of the earlier published text for their reference like Senart, Nesfield, Risley. Dumont and Ambedkar mentions with

\footnotetext{
3 Dumont, Louis, homo hierarchius ,p-48

${ }^{4}$ Ambedkar, B.R., castes in India. 2013, critical Quest New Delhi . p-6
} 
reservation that Brahmins as the renounces were the creators of value and different branches of Knowledge .

Differences- According to Dumont caste plays a positive function and abolition of such pure institution or system is impractical. For Ambedkar Caste system is a negative thing as it prohibit persons belonging to different castes from intermarrying. It is not a positive method of selecting, which two among a given caste should marry ${ }^{6}$. Ambedkar argues that the ideal of social organisation is chaturvarnya or the division of classes instead of the four thousand castes that we have in India. Chaturvarnya is based not on Birth but on Guna (worth). For him chaturvarnya is impractical, harmful and has turned out to be a miserable failure. Caste is different from varna and even fundamentally opposed as former is based on worth ${ }^{7}$. The problem of caste, then ultimateley resolves itself into one of repairing the disparity between the marriageable units of the two sexes within this context Ambedkar talks about Concept of surplus man and women. While Dumont does not talk about surplus man and women.

What is to be done to abolish Caste- According to Ambedkar Caste is a notion; it is a state of Mind. It is the religion which inculcates the notion of caste. Shastras teach religion. Inter- dining and intermarriage are repugnant to the beliefs and dogmas, which the Hindus regard as Sacred. According to Ambedkar the real remedy for breaking caste is inter- marriage and inter- dinning, and destroy the belief in the sanctity of the shastras, emphasing on the stand of Bhuddha and Nanak on not only discard shastra but must deny their authority. Nothing else will serve as the solvent of caste. ${ }^{8}$ For Dumont caste plays a positive function and abolition of such pure institution or system is impractical therefore he has not given any kind of solution or remedy to abolish caste.

In my opinion Ambedkar was able to suggest all the above solution to caste system is because of the fact that he was an Indian, that to belong to Mahar Jati i.e. Scheduled caste, experience (lived experience) plays an important epistemological role in production of thoughts. Experience is prior to thinking and knowing. For him existing society is driven by text like Manu smriti, which has formidable cognitive influence on conservative social consciousness. This makes it difficult for Dalits or women to rely on such texts. Whereas for Dumont, India was a foreign Land and he did not have lived experience also that's way unable to produce any solution for abolishing caste.

\section{References}

1. Dumont, Louis. Homo Hierarchicus The Caste System and its Implications.

2. Ambedkar, B.R., 2013, Castes in India, Critical Quest Publisher, New Delhi.

3. Ambedkar, B.R., 2007. Annihilation of caste. Critical Quest Publisher, New Delhi.

\footnotetext{
${ }^{5}$ (Dumont 1980:275),

${ }^{6}$ Ibid. p-16

${ }^{7}$ Ibid. p- 27

${ }^{8}$ Ibid p-38
} 